\title{
부산총회의 결과와 KOICA 개발협력 사업에 대한 함의
}

임 소 진 KOICA ODA연구실 상임연구원

\section{목 차}

I. 서론

II. 부산총회의 결과

III. 부산총회와 KOICA의 과제 및 방안

IV. 결어

\section{I. 서론}

부산총회는 160 여 개의 공여국과 수원국을 비롯하여 다자기관, 시민사회, 민간분야, 의회 및 전문 가들이 한자리에 모여 새천년개발목표(Millennium Development Goals, MDGs)를 위한 성과 최대화 에 기여하고 총회 이후 효과적 개발을 위한 새로운 프레임워크에 동의하고 참여하는 기회가 되었다. ${ }^{1)}$ 원조효과성을 위한 고위급회담의 마지막 회의였던 부산총회는 합의도출이 가능한 공감대 형성을 위해 개발협력의 모든 주체를 포함하고 그들의 다양성 및 상호보완성을 인정하려 노력하였고, 이를 통해 중 국, 인도 및 브라질 등 신흥공여국들이 자발적으로 부산결과문에 합의하도록 하였다.2) 그 결과 참여 국가들의 정치적 지지를 확보하는 정치적 선언문(Political Statement)을 채택하는 성과를 거두었다.

또한 부산총회는 원조효과성을 넘어선 포용적 성장(inclusive growth)을 목표로 하는 개발효과성 으로의 패러다임 변화 및 새로운 글로벌 파트너십 구축이라는 성과를 거두었다. 뿐만 아니라, 네 차 례에 걸친 고위급회담를 모두 $\mathrm{OECD}$ 가 주도해왔다면, 부산총회 이후의 체제는 $\mathrm{OECD}$ 와 $\mathrm{UN}$ 의 연계 체제로 전환될 것이다. 이를 바탕으로 개발효과성 뿐 아니라 MDGs 목표달성을 위해 OECD와 UN을 중심으로 국제 개발협력 사회가 함께 노력할 것이다.

1) Abdel-Malek and Koenders, 2011

2) OECD, 2011 
MDGs 목표달성 및 효과적 개발을 통한 전세계 빈곤퇴치를 위해 공여국과 수원국을 포함한 개발주 체들은 2012년 6월까지 부산이후 체제 이행 모니터링을 위한 평가지표를 개발할 계획이다. 이를 위하 여 한국정부는 부산이후 체제이행 평가지표 개발에 적극적으로 참여할 의지를 보이고 있다. 또한 ODA 이행기관인 KOICA 또한 부산이후 체제에 발맞추어 변화를 가져올 것으로 예상된다. 이와 관련하여, 본 연구는 부산총회 결과문서를 분석한 후, 부산총회 이후 체제와 관련된 KOICA 개발협력 사업의 과 제 및 발전방안에 대해 논의해보고자 한다.

\section{II. 부산총회의 결과3)}

2011년 부산총회에서 채택된 결과문(Busan Outcome Document, BOD)의 주요내용은 다음과 같다.

\section{4대 공동원칙과 이에 따른 행동방안}

공여국, 수원국, 다자기관 및 공공기관, 시민사회, 민간기업, 의회 및 지역기구들은 부산총회의 결 과문서를 통해 새로운 파트너십에 의한 효과적인 국제개발을 위한 공동 원칙과 목표를 강조하였다. 또한 2015년 목표인 MDGs의 달성 의지를 표명하였다. 이번 부산결과문에서는 다음과 같은 4대 공 동원칙과 그에 따른 4 가지 행동방안을 제시하였다.

\section{〈표 1〉 2011 부산총회에서 채택된 4대 공동원칙과 행동방안}

\begin{tabular}{l|l}
\multicolumn{1}{c|}{ 4대 공동원칙 } & \multicolumn{1}{c}{ 공동원칙에 따른 행동방안 } \\
\hline $\begin{array}{l}\text { 개발 우선과제에 대한 개발도상국의 주인의식 } \\
\text { (Ownership of Development Priorities by Developing Countries) }\end{array}$ & $\begin{array}{l}\text { 개발정책 및 절차의 민주적 주인의식 심화, } \\
\text { 확대, 운용 }\end{array}$ \\
\hline $\begin{array}{l}\text { 결과중심 } \\
\text { (Focus on Results) }\end{array}$ & $\begin{array}{l}\text { 구체적이고 지속가능한 개발성과를 위한 노 } \\
\text { 력 강화 }\end{array}$ \\
\hline $\begin{array}{l}\text { 포용적 개발 파트너십 } \\
\text { (Inclusive Development Partnerships) }\end{array}$ & \begin{tabular}{l} 
남남협력 및 삼각협력에 대한 지원 확대 \\
\hline $\begin{array}{l}\text { 투명성 및 상호책임성 } \\
\text { (Transparency and Accountability to Each Other) }\end{array}$
\end{tabular} \\
\hline
\end{tabular}

출처 : 저자 작성, 참고 $\mathrm{OECD}, 2011 \mathrm{~b}$

국제사회는 부산선언의 4대 공동원칙과 행동방안 이행을 위하여 2012년 6월까지 소수의 선택적 평가지표를 개발하기로 결의하였다.

3) 본 연구의 '부산총회의 결과’ 부분은 동 저자가 작성한 'KOICA 개발협력 정책과 이슈 3호(2011년12월)'에서 발췌하였다. 


\section{2. 변화 실현을 위한 보완적 행동방안}

부산결과문에서 개발협력 주체들은 위와 같은 4대 공동원칙과 그에 따른 행동방안 이외에 2015년 $\mathrm{MDGs}$ 달성을 향한 효과적 개발을 위해 변화가 필요하다고 보았고, 그 변화를 위하여 다음과 같은 부수적인 행동방안이 필요하다고 뜻을 모았다.

\section{1) 공동원칙 및 차별화된 공약을 중심으로 국제원조체계(Aid Architecture)의 새로운 개발주체 포용}

북남(North-South) 패러다임에서 시작한 국제 개발협력 구조는 오늘날 부상하는 남남 (South-South) 개발협력으로 인해 새로운 참여자들을 맞이하게 되었다. 그러나 파리선언에서는 복 잡한 국제원조체계에서 새로운 개발주체에 대한 논의가 없었고, 아크라 행동강령을 통해 신흥공여국 및 시민사회 등 새로운 개발주체에 대한 중요성이 대두되었다. 금번 부산총회에서는 포괄적 개발 아 젠다 형성을 위해 이런 새로운 참여자들을 논의에 포함시킴으로써, 남북협력과 남남협력의 차별성 및 보완성 그리고 공동원칙 및 차별화 된 행동을 인정하였다.

\section{2) 개발협력의 질과 효과성 향상}

파리선언과 아크라 행동강령을 통해 약속된 공약들이 원조의 질적 향상과 투명성 그리고 개발협력의 효과성 제고에는 기여하였으나, 효과적 개발을 위해서는 아직 더 많은 노력이 필요하다. 부산총회를 통 하여 그동안의 전통적인 원조 관계자들 뿐 아니라, 남남협력, 삼각협력 및 시민사회 등이 모두 함께 파 리선언과 아크라 행동강령의 뜻을 이어 부산에서 채택된 공동원칙들에 대한 공약을 확실히 하고, 그 공 약들이 이행될 수 있도록 하기 위한 고위급 정치적 리더십을 유지할 필요가 있다고 강조하고 있다.

또한 부산선언에서는 파리선언 모니터링 결과를 반영하여 지속적인 결과를 중심으로 한 개발을 위한 파트너십의 효과성 향상에 필요한 변화를 촉구하였다. 이러한 변화를 위해서는 앞으로 1) 주인의식, 결 과 및 책임성 강화; 2) 투명하고 책임 있는 협력; 3) 분쟁 및 취약한 상황에서의 지속가능한 개발의 촉진; 4) 재난 상황에서의 복원력 강화 및 취약성 감소를 위한 공조가 필요하다고 제시하고 있다.

\section{3. 효과적 원조에서 효과적 개발을 위한 협력으로}

금번 부산총회에서는 원조만이 개발을 위한 해답이라는 관점을 벗어나 더 광범위한 의미로써 효과 적 개발에 대해 논의하면서, 다음과 같은 요소들을 포함한 프레임워크의 필요성을 제시하였다.

$\triangleright$ 개발은 강력하고 지속가능하며 포용적 성장에 의해 주도된다. 
$\triangleright$ 정부가 소유한 재원은 개발에 필요한 재정에 더 많은 역할을 담당한다. 이로써 정부는 달성한 개발 성과에 대해 국민들에게 좀 더 많은 책임을 질 수 있다.

$\triangleright$ 효과적 정부 및 비정부기관은 자체적 개혁을 설계 및 실행하고 서로에 대한 책임을 갖는다.

$\triangleright$ 개도국은 세계경제에서 보다 나은 경쟁 우위를 확보할 수 있는 규모의 경제를 형성하면서 점차 적으로 지역적 그리고 세계적으로 통합된다.

이 프레임워크를 통해 국제사회는 앞으로 원조가 어디에 어떻게 쓰여야 하는지에 대해 재고해야 하며, 원조가 국제적으로 동의된 권리, 규범 및 기준과 일치하여 개발을 위한 촉매적 역할을 해야 한 다고 정의하고 있다.

부산총회 결과문은 효과적 제도와 정책이 지속가능한 발전에 필수요건이라고 강조하면서, 개도국 들은 지역적 특성과 각기 다른 단계의 개발을 수용하며 효과적 제도 강화를 위한 노력을 주도해야 한 다고 설명한다. 이와 관련하여 공여국 및 수원국의 정상들은 개도국의 효과적 제도 설립을 위하여 개 발협력의 주체들이 다음과 같은 사항을 위해 노력해야 할 것이라고 합의하였다.

$\triangleright$ 개도국에 의해 주도된 제도적·정치적 변화 실행 지원

$\triangleright$ 개도국에 의해 주도된 국가기관(institutions), 제도(systems) 및 역량개발의 필요성에 대한 평가

$\triangleright$ 정책입안, 이행 및 책임을 보여줄 수 있는 개도국에 의해 주도된 제도적 성과 향상 결과에 대한 발전 지원

$\triangleright$ 제도개혁, 지역 및 국제적 차원에서의 지식 및 경험의 교류를 위한 성공 요인(determinants)에 대한 학습(learning) 심화

부산결과문서에 실린 효과적인 개발을 위한 협력방안은 다음과 같다.

\section{1) 지속가능한 개발을 위한 남남협력 및 삼각협력}

금번 부산총회에서는 아크라 행동강령을 통해 대두된 남남협력과 삼각협력을 지속가능한 개발을 위한 잠재적 요소로 정의하고 있다. 즉, 지속가능한 개발에 있어서 재정적 협력을 넘어선 지식 및 개 발경험의 공유가 모든 관계자들 및 국가들에게 중요하며, 남남협력과 삼각협력이 개도국의 국가적 맥락에서 시너지 효과를 가져올 수 있다고 보고 있다. 또한 지식공유와 상호학습을 강화하기 위해 개 발협력 주체들은 다음과 같은 사항을 이행해야 한다고 서술하고 있다.

$\triangleright$ 적절한 상황에서, 개발협력으로의 삼각협력 방법 이용 증진 
$\triangleright$ 남남협력과 삼각협력에 대한 더욱 활발한 이용

$\triangleright$ 개도국에 의한 중요한 지식풀(knowledge pools)로의 접근성 강화수단으로써 남남협력 주체간 지식교류, 상호학습(peer learning) 및 협력 네트워크 개발 장려

$\triangleright$ 남남협력과 삼각협력에 효과적으로 참여할 수 있는 지역 및 국가 역량 강화를 위한 노력 지원

\section{2) 민간부문과 개발}

부산총회에서는 남남협력 및 삼각협력에 대해 아크라 고위급회담과 비교하여 좀 더 심도있게 다루 고 있을 뿐 아니라, 개발에 있어서 민간분야의 역할에 대해서도 논의하였다. 특히 혁신 주도, 부와 소득 및 일자리 창출, 국내 재원의 동원 그리고 이러한 요소들로 인한 빈곤퇴치에 있어서 민간부문의 역할을 강조하였다. 부산결과문은 개발협력에서 민간분야 역할을 활성화하기 위해 다음과 같은 사항 을 위해 노력할 것을 결의하였다.

$\triangleright$ 민간투자 개발을 위한 법적, 규제적, 행정적 환경을 향상시키기 위한 비즈니스 협회 및 노동조 합 등의 대표들과의 연계(engage) 및 민간부문 개발, 증가된 외국인직접투자(foreign direct investment, FDI), 민관 파트너십(public-private partnership, PPP), 가치 사슬(value chain) 의 강화 등을 위한 건전한 정책 및 규제적 환경 보장

$\triangleright$ 지속가능한 성장과 빈곤 퇴치를 위한 개발 정책 및 전략의 설립 및 이행 단계에서 민간분야의 참여 확대

$\triangleright$ 공동의 개발목표를 위한 민간재원을 동원하기 위한 혁신적 금융체계의 발전 심화

$\triangleright$ 지속가능한 발전을 위한 '무역을 위한 원조(Aid for Trade)' 장려

$\triangleright$ 개발과 사업성과(business outcomes)를 증진시키는 방법 모색을 통해 상호 보강 효과를 누릴 수 있도록 민·관 분야의 대표 및 관련 기관의 대표를 개발협력의 주체로 참여 장려(invite)

\section{3) 부패 및 불법적 흐름(illicit flows)의 방지}

부패는 세계적으로 개발을 저하시키는 심각한 요인이 되고 있다. 이에 부산총회 결과문에 동의한 국가들은 특히, 유엔반부패협약(UN Convention Against Corruption)과 OECD뇌물방지협약(OECD Anti-Bribery Convention)과 같은 국제협정과 일관된 부패와 불법자금을 방지하는 노력을 강화하기 로 하며, 이를 위해 다음의 두 가지 사항의 이행을 위한 노력에 합의하였다.

$\triangleright$ 반부패 법 강화 및 부패한 행동에 대한 무관용의 문화 촉진을 통한 부패근절에 대한 각각의 공 약에 대한 충실한 이행

$\triangleright$ 자금세탁방지 조치(measures) 강화, 조세회피에 대한 자제 촉구, 불법자산에 대한 추적, 동결 
및 회수를 위한 국가적·국제적 정책, 법적 프레임워크 및 제도적 장치 강화 등의 불법자금 방 지를 위한 각각의 노력 가속화

\section{4) 기후변화 재원}

금번 부산총회에서는 기존의 고위급회담에서 중요시 하지 않았던 국제 기후변화 재원(finance)에 대해서도 논의하였다. 개발협력의 주체들은 효과적인 기후 재원 및 넓은 의미의 개발협력을 위하여 다음의 두 가지 사항을 포함한 일관성, 투명성 그리고 예측성을 고려한 노력을 촉구하기로 하였다.

$\triangleright$ 개도국의 전체 국가개발계획의 필수적인 부분으로의 국가 기후변화 정책 및 계획에 대한 지원 지속

$\triangleright$ 기후 활동 참여 주체들과의 개발 효과성과 관련된 교훈 공유 지속

\section{MDGs 목표달성 및 그 이후의 발전을 위한 협력}

개발협력의 주체로서 부산총회 결과문서에 합의한 국가들은 앞으로 파리선언 및 아크라 행동강령의 원 칙들과 함께 다음과 같은 사항을 이행할 것이다. 또한 지금까지 파리선언 및 아크라 행동강령 이행평가는 $\mathrm{OECD}$ 의 주도하에 이루어졌으나, 부산총회에서 합의된 내용에 대한 이행 모니터링과 평가는 $\mathrm{OECD}$ 외에 유엔 개발협력포럼(UN Development Cooperation Forum, 이후 UN DCF)이 자문역할을 할 것이다.

\section{〈표 2〉부산총회 이후의 이행체제(Post-Busan Mechanism)}

\section{파리선언, 아크라 행동강령, 부산총회 이행을 위한 공약}

- 개도국 주도의 이행 프레임워크 구축 및 발전결과 대중공개

-Post-MDGs 프레임워크를 포함한 부산 공약 이행을 위한 선택적 평가지표 개발 (개발목표 : 2012년 6월까지)

- 모니터링 역량 강화 및 개발효과성 향상 노력을 평가하는 개도국 주도의 이니셔티브 지원

부산총회 이후 새로운 협력체제를 위한 이행방안

- 새롭고 포괄적인 '효과적 개발협력을 위한 글로벌 파트너십(Global Partnership for Effective Development Cooperation)' 구축

-2012년 6월까지 글로벌 파트너십을 위한 가벼운(ight) 형태의 운영방안에 대해 합의

- 2012년 6월에 설립될 새로운 체계 및 기존의 OECD 원조효과작업반(Working Party on Aid Effectiveness, WP-EFF)의 역할 마무리, 그리고 글로벌 파트너십을 위한 잠정적 결정 및 부산결과문 지지

- 글로벌 파트너십의 효과적 기능 지원을 위한 OECD와 UNDP 협력 장려 


\section{III. 부산총회와 KOICA의 과제 및 방안}

\section{1. 부산총회 이후 이행체제에 관한 $\mathrm{KOICA}$ 의 당면과제}

부산에서 합의된 공약을 이행하고 개발효과성 향상을 통한 수원국 발전에 기여하기 위하여 한국정 부와 KOICA 모두에게 우선적으로 주어진 과제는 부산총회에서 채택된 4대 공동원칙에 대한 명확한 이해와 행동방안의 마련이다. 파리선언 이행결과 한국은 23 개의 공여국 중 이태리, 스위스, 터키 그 리고 미국과 함께 최하위권에 머물렀다. ${ }^{4)}$ 파리선언의 이행을 위한 범정부적 정치적 지지도 미흡하였 지만, ODA 집행기관인 KOICA 내부의 파리선언 원칙과 지표에 대한 정확한 이해 및 변화를 위한 방 안 고려 역시 부족하였기 때문이다.

파리선언 결과보고서에 따르면 일부 공여국과 수원국들이 파리선언의 5 대원칙과 13 개 지표의 정의 및 측정방법에 대해 의도된 바와 다르게 해석하여, 이행 결과보고에 있어서도 잘못된 평가를 한 것을 알 수 있다.5) 예를 들어 한국의 경우, 2006년과 2008년 수원국의 공공 재정관리 시스템 활용정도(지 표 $5 \mathrm{a}$ )에 관하여 각각 $45 \%$ 와 $10 \%$ 로 보고하였으나, 이는 대외경제협력기금(Economic Development Cooperation Fund, 이하 $\mathrm{EDCF})$ 의 유상 차관에 관한 평가로 보고된 것이었으며, 실제 파리선언이 정 의하는 무상 원조 중에는 해당액이 없었던 바, 한국의 지표 $5 \mathrm{a}$ 에 대한 실제 기여도는 $0 \%$ 에 해당된다. ${ }^{6)}$

그러나 파리선언 이행 실패가 비단 평가지표에 대한 이해부족에서 비롯된 것만은 아니다. 파리선 언의 5 대원칙과 13 개 지표는 선진공여국 주도하에 그들의 원조관리시스템(aid management system)과 원조방법(aid modality)에 기초하여 개발되어, 한국처럼 선진공여국과 다른 시스템을 갖 춘 공여국들이 이행할 수 있는 지표들이 제한되었던 것도 사실이다. ${ }^{7)}$ 비록 이른바 $\mathrm{OECD} \mathrm{DAC} \mathrm{공여}$ 국의 원조모델이 지향되고 $\mathrm{OECD}$ 권고사항에도 한국의 원조모델이 변화되어야 한다는 권고가 있어 왔으나, ${ }^{8)}$ 현실적으로 한 국가의 원조관리시스템을 5 년이라는 단기간에 바꾸어 파리선언 원칙을 이 행하기에는 시작부터 쉽지 않은 일이었다.

그러나 부산총회를 계기로 국제 개발협력의 리더로서 자리매김을 하고자 하는 시점에서 한국은 더 이상 선진공여국과 다른 원조형태를 이유로 국제사회가 요구하는 개발협력 모델을 간과할 수 없는 일 이다. 그러므로 한국 ODA의 실질적 이행기관인 KOICA는 파리선언에 대한 재분석 및 부산 이후 체제
4) OECD, 2011a
5) Wood et al., 2008
6) 이현주, 2010a
7) $\mathrm{Lim}, 2011$
8) OECD, 2008d 
에 대한 명확한 이해를 통하여 국제사회가 요구하는 원조 및 개발효과성을 위한 방안과 한국 원조시스 템 및 원조방법 그리고 KOICA 사업의 현실을 재조명하여 변화를 위한 방안을 모색하여야 할 것이다.

이를 위해 KOICA는 다음과 같은 사항에 대한 고려를 시작으로 부산총회 4대 공동원칙과 부산총회 이후 체제에 부합하는 구체적이고 실질적인 이행방안을 마련해야 할 것이다.

\section{2. 부산총회 4 대 공동원칙에 부합하는 이행방안을 위한 우선적 고려사항}

\section{1) 수원국 주인의식 강화를 위한 국별협력전략(CPS)의 활용}

앞에서 본 바와 같이 이번 부산총회는 수원국 주도의 주인의식을 강조하였다. 파리선언 및 아크라 행동강령을 통해서 지속적으로 강조된 주인의식 원칙에 수원국 주도라는 내용을 추가함으로써, 수원 국 중심의 개발을 강조하고 있는 것이다.

KOICA는 현재 국별협력전략(Country Partnership Strategy, 이후 CPS)을 통해 공여자 중심의 개발 원조를 지양하고 수원국의 주인의식을 제고할 수 있는 방안을 추진하고 있다. ${ }^{9)}$ 구체적으로 CPS는 수원 국의 빈곤감소 전략 보고서(Poverty Reduction Strategy Paper, PRSP) 및 개발계획(Development $\mathrm{Plan}$ )과 KOICA 의 ODA 사업일치를 통한 주인의식 강화를 목표로 하고 있다. 또한 KOICA는 CPS를 중 심으로 수원국과의 협의를 통한 ODA 지원계획을 수립하여 보다 효과적으로 수원국의 필요를 바탕으로 한 빈곤퇴치 및 지속가능한 개발을 지원하고자 노력하고 있다. KOICA는 앞으로 CPS를 보다 적극적으 로 활용하여 수원국 주인의식 함량에 이바지할 수 있을 것이다.

그러나 정부의 예산공개가 아직 이루어지지 않아 수원국이 요구하는 중기지원계획을 수립하기는 어려운 실정이다. 금번 부산총회에서 요구된 수원국의 개발 우선과제에 대한 주인의식 강화를 위해 $\mathrm{KOICA}$ 의 중기지원계획을 제공하는 것도 중요한 바, $\mathrm{KOICA}$ 뿐 아니라 정부적 차원에서 예산공개를 통한 수원국 주인의식 강화 및 개발계획 발전에 기여할 수 있어야 할 것이다.

\section{2) 결과중심을 위한 성과평가틀 통합관리 및 개발사업의 프로그램화}

부산총회 두 번째 공동원칙은 결과중심으로 공여국 및 수원국의 구체적이고 지속가능한 개발성과 를 위한 노력 강화를 권유하고 있다. 이와 관련하여 KOICA는 국제사회 기준에 알맞은 성과평가를 바 탕으로 원조사업을 추진할 필요가 있다. 그러나 현재 KOICA 개발사업 성과평과와 관련하여 국외로 는 파리선언 및 부산공약 이행평가, OECD DAC의 개발협력정책집행평가(DAC Peer Review), 국제개

9) 한국국제협력단, 2011 
발센터(Center for Global Development, 이후 CGD)의 개발공헌지수(Commitment to Development Index, 이후 CDI)와 ODA 질적평가(Quality of Official Development Assistance, 이후 QuODA), 국 내로는 기재부 심층평가 및 외교부 산하기관 평가, 그리고 KOICA 내부적으로는 프로젝트별 사업평 가 등 여러 평가틀이 상호간 체계적 연계없이 운영되고 있는 실정이다 (표3 참조).

\section{〈표 3〉 KOICA 사업에 대한 국·내외 원조 성과평가의 예}

\begin{tabular}{l}
\multicolumn{1}{c}{ 국외 국별 원조 비교평가 } \\
\hline$\circ$ 파리선언/Post-Busan \\
$\circ$ 개발협력졍책집행평가 (DAC Peer Review) \\
$\circ$ 국제개발센터 개발공헌지수 (CGD CDI) \\
$\circ$ 국제개발센터 ODA 질적평가 (CGD QUODA) \\
\hline \multicolumn{2}{c}{ 국내 원조 기관평가 } \\
\hline$\circ$ 기재부 공공기관 평가 \\
$\circ$ 외교부 산하기관 평가 \\
\hline \\
\hline K프로젝트별 사업평가
\end{tabular}

$\mathrm{KOICA}$ 는 $\mathrm{ODA}$ 연구실에서 진행 중인 '통합 성과관리 체계 구축 방안'에 관한 연구 결과를 바탕으로 국-내외 성과평가 통합관리 전담 부서를 마련하여 상기 평가틀에 대한 통합적 관리를 할 필요가 있 다. 또한 성과평가 종류에 따른 부서별 분담체계 마련방안에 대한 고려도 필요하다. 이와 관련하여 성과관리를 위한 개선방안 및 실행체계 관련 토론회 등을 실시하여 '통합 기관성과 관리제도'를 구축 할 수 있을 것이다.

이와 같은 원조 성과평가 통합관리를 통하여 파리선언 및 부산총회 이후 체제 모니터링 지표와 같 은 국외평가 및 개별 평가지표에 대한 인식 및 이해도를 높이고 적절한 대응방안을 마련할 수 있을 것이다. 예를 들어 파리선언 및 QuODA 지표 중 ‘수원국 행정부담 경감' 분야에서 한국의 기여도가 미흡한 바,10) $\mathrm{KOICA}$ 는 '수원국 행정부담 경감'과 같이 여러 성과평가에서 반복되는 지표의 집중 관 리 및 구체적 개선방안을 강구해야 할 것이다.

이와 관련하여, 유수 국외 원조 성과 지표들이 수원국의 행정부담 경감을 평가하고 있는 이유는 공 여국의 파편화로 인한 과다한 개발 프로젝트 수가 수원국에게 부담이 되고 있으며, 또한 단위 프로젝 트 예산이 낮은데 기인하기 때문이다. ${ }^{11)}$ 그러므로 $\mathrm{KOICA}$ 는 국별 유사 프로젝트를 특정 프로그램의

10) Birdsal and Kharas, 2010, 2011 
하위 실행 사업으로 그룹화 또는 패키지화하여 프로그램 단위로 평가하는 방법을 시작으로, 점차적인 프로그램형 원조(Program-Based Approach, 이후 PBA)로의 변화를 가져오는 방안을 고려해야 한다. 나아가 현재 추진중인 CPS 사업과 연계하여 현실을 고려한 PBA 도입을 고려할 수도 있을 것이다. ${ }^{12)}$

부산총회에서 수원국 중심의 개발을 강조하고, 이후 이행체제를 위한 지표개발에서 수원국의 행정 부담 경감 조항이 배제될 확률은 매우 낮다. 그러므로 KOICA는 앞으로 프로젝트 중심의 사업을 배제 하고 프로그램화 할 필요가 있다.

\section{3) 포용적 개발 파트너십 강화를 위한 삼각협력 지원 강화}

부산총회 4대 공동원칙 중 세 번째는 남남협력 및 삼각협력에 대한 지원 확대를 통한 포용적 개발 파트너십 강화이다. KOICA는 이미 기존 연구를 통해 비용효과성과 사업의 질적측면을 중심으로 국 가 집약적이고 중장기적인 추진, 기존 KOICA 사업과의 연계, KOICA 해외 사업수행 역량과의 균형 등의 삼각협력 추진방향에 대한 방안을 고려해왔다. ${ }^{13)}$ 그러나 KOICA는 아직까지 삼각협력(남-남북)이라기보다 '삼자간 협력(남-북-북)'에 가까운 지원을 제공하고 있다. 부산 공약의 이행을 위하여 $\mathrm{KOICA}$ 는 지금까지의 삼자간 협력의 경험을 기반으로 삼각협력 사업에 부합하는 방안을 마련할 수 있을 것이다. 또한 삼각협력에서 직접적 지원의 대상이 되는 남측공여국 선정과 협력분야 및 구체적 방식에 대한 논의가 필요할 것이며, 나아가 신흥공여국의 역량강화를 통한 남남협력 강화를 위한 지 원 방안도 고려할 수 있을 것이다.

\section{4) 투명성 및 상호책임성 강화를 위한 정보공개 심화}

부산총회 4 대 공동원칙의 마지막으로 원조의 투명성 및 책임성이 강조되었다. 특히 이번 마지막 고위급회담에서는 파리선언 및 아크라 행동강령 이행경험에 비추어 공여국의 국제투명성기구 (International Aid Transparency Initiative, 이후, IATI) 가입여부 및 원조 정보공개(open data)가 주목되었다. 국제사회와 시민사회의 공여국에 대한 이러한 요구에 힘입어 그동안 가입을 꺼려하던 미국도 부산총회를 계기로 IATI에 가입하여 국제사회가 요구하는 기준에 맞추어 원조 정보를 공개하 기로 하였다. 이와 같은 국제사회의 움직임 속에 한국 정부도 IATI 가입 등을 통한 투명성 강화 지원 을 고려해야 할 것이다.

정보공개와 관련하여 KOICA는 이미 OECD DAC에 공여국 자진 보고체계인 $\mathrm{CRS}$ (Creditor

11) 이현주, $2010 b$

12) 본 연구에서는 왜 PBA를 도입해야 하는지에 대해 다루지는 않으나, PBA가 그 효과성에 대한 검증이 이루어지지 않았 음에도 불구하고 '수원국의 개발 프로그램을 활용하기 위한 방법' 및 공여국간의 '원조조화'를 위한 방안으로 사용될 수 있다는 점에서 부산총회 이후 이행체제에서도 국제사회는 지속적으로 PBA의 사용을 권장할 것인바, KOICA는 PBA 의 사용을 적극 고려해야 할 것이다.

13) 이현주, 2009 
Reporting System) 보고를 지속적으로 해오고 있으나, 투명성 평가에서는 아직 부족한 점이 많다. 예를 들어 아크라 고위급회담 이후 형성된 Publish What You Fund의 2011년 원조 투명성 사전 평 가(Pilot Aid Transparency Index)에서 KOICA는 공여기관 평균치인 34\% 보다 조금 높은 37\%를 기 록하였으나(그림1 참조), 전체 순위로 보았을 때 원조 투명성이 미흡한 국가 그룹(poor)에 속하는 것 을 알 수 있다(그림2 참조).

\section{〈그림1〉Publish What You Fund 2011년 원조 투명성 사전평가 결과 (\%)}

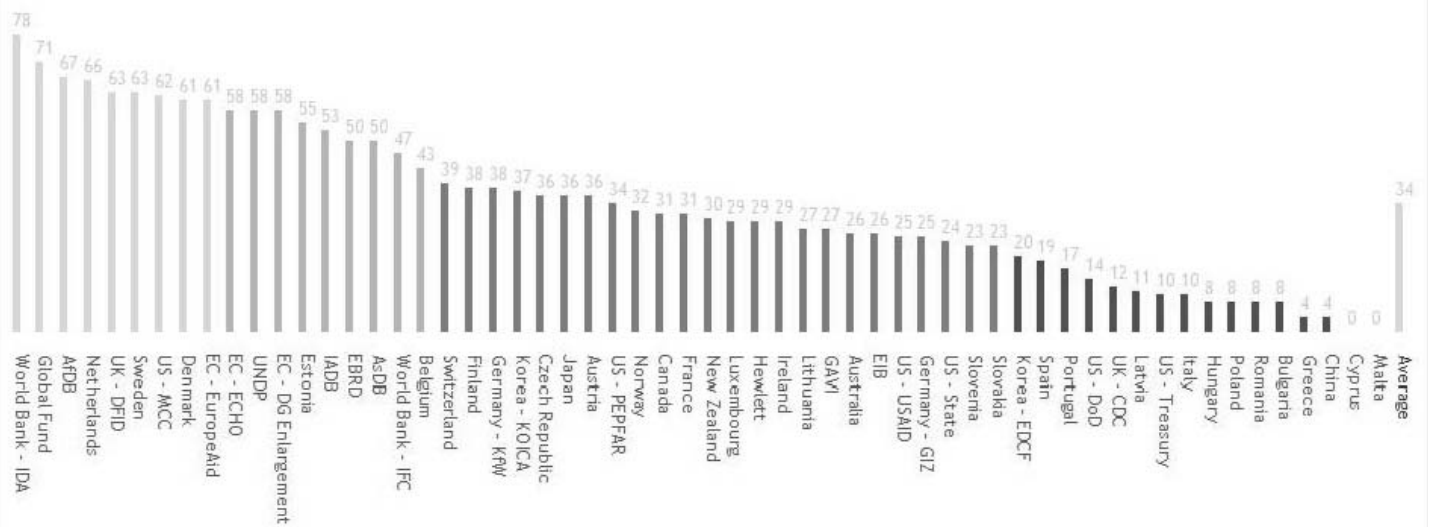

출처 : Publish What You Fund, 2011

\section{〈그림2〉 Publish What You Fund 2011년 원조 투명성 사전평가 순위}

Fair
$\begin{array}{ll}\text { 1. World Bank - IDA } & \text { 1. UNDP } \\ \text { 2. Global Fund } & \text { 2. EC-ECHO } \\ \text { 3. AfDB } & \text { 3. EC - DG Enlargement } \\ \text { 4. Netherlands } & \text { 4. Estonia } \\ \text { 5. UK-DFID } & \text { 5. IADB } \\ \text { 6. Sweden } & \text { 6. EBRD } \\ \text { 7. US-MCC } & \text { 7. ASDB } \\ \text { 8. Denmark } & \text { 8. World Bank - IFC } \\ \text { 9. EC-EuropeAid } & \text { 9. Belgium }\end{array}$

\section{Poor}

1. Switzerland

2. Finland

3. Germany - KfW

4. Korea-KOICA

5. Japan

6. Czech Republic

7. Austria

8. US - PEPFAR

9. Norway

10. Canada

11. France

12. New Zealand

13. Ireland

14. Luxembourg

15. Hewlett

16. Lithuania

17. GAVI

18. Australia

19. EIB

20. US - USAID

21. Germany - GIZ

22. US - State

23. Slovenia

24. Slovakia

25. Korea-EDCF

출처 : Publish What You Fund, 2011 
따라서 원조효과성 나아가 효과적 개발협력을 위한 중요한 사항인 투명성 강화를 위하여 KOICA는 IATI 등이 요구하는 국제기준에 부합하는 정보공개에 대비해야 할 것이다.

\section{3. 그 밖의 효과적 개발협력을 위한 KOICA의 과제}

\section{1) 최빈국 및 취약국에 대한 체계적 지원 고려}

아크라 고위급회담에서 가속화 된 최빈국 및 취약국에 대한 지원방안 논의가 부산총회에서 더욱 심화 되었다. $\mathrm{KOICA}$ 는 이라크 및 아프가니스탄과 같은 취약국에서 전쟁 및 자연재해 등을 겪은 국가들을 대 상으로 하는 '해외재난 복구지원'을 통한 재건복구 지원사업을 제공하였고, 그 외 '국제빈곤퇴치기여금 사업'을 통해 취약국을 지원해 오고 있다. 그러나 현재 KOICA 원조사업의 대부분은 26 개의 중점협력국 을 중심으로 이루어지고 있으며, 최빈국 및 취약국에 대한 지원은 단기간에 이루어지고 있는 실정이다. 또한 지원정책 수립 및 집행과정에서 최빈국 및 취약국에 관한 별도의 고려가 이루어지지 않고 있다. ${ }^{14)}$ 따라서, $\mathrm{KOICA}$ 는 앞으로 늘어나는 원조액 집행에 대비하여 최빈국 및 취약국을 위한 체계적 지원을 고 려해야 할 것이며, 이들 국가의 원조관리 시스템 강화를 위한 역량개발 방안도 마련해야 할 것이다.

\section{2) 새로운 글로벌 파트너십을 위한 타 공여기관과의 협력 강화}

부산총회에서 국제 개발협력 주체들은 새로운 포괄적 글로벌 파트너십을 구축하는데 합의하였다. 새로운 글로벌 파트너십은 파리선언의 원조조화와 아크라 행동강령의 남남협력 및 삼각협력을 강화하 고, 시민사회 및 민간분야와의 협력을 포함하는 개념이다. 그러나 무엇보다도 부산 글로벌 파트너십은 포괄적 협력을 통한 수원국 부담 경감과 수원국 주도의 발전을 지원하는데 그 근본적 취지가 있다.

이러한 점을 상기하였을 때, $\mathrm{KOICA}$ 는 특히 현장에서의 타 공여기관과의 협력을 강화할 필요가 있 다. 예를 들어 위에서 언급된 국외 여러 원조 성과평가 지표들이 포함하고 있는 '수원국 내 원조기관 들의 현지사무소 및 행정 공유'와 '공동연구 및 통합보고서 제작'을 위한 타 공여기관과의 협력 강화 를 통해, 각 공여국이 개별적으로 요구하는 문서작업에 대한 수원국의 부담을 경감하는 효과를 도출 할 수 있을 것이다.

\section{3) 해외사무소 실무인력 증대 및 본부와 해외사무소간 커뮤니케이션 개선}

위와 관련하여, 언어적 현실(language transaction) 및 부족한 해외사무소 실무인력 등의 이유로 그동안 타 공여기관과의 협력이 쉽게 이루어지지 않고 있었다. 예를 들어 탄자니아에서는 개발파트

14) 권혁주 외, 2011 
너그룹(Development Partners Group, 이후 DPG)을 통해 공여국들이 원조 프로그램에 대한 수원국 부담을 경감하고, 통합 모니터링 체계 및 공동연구 등을 위한 협력을 해오고 있다. ${ }^{15)}$ 그러나 KOICA 탄자니아 사무소는 2 명(소장, 부소장)의 실무인력이 탄자니아 내 원조사업을 관리하고 있는바,16) $\mathrm{DPG}$ 참여가 현실적으로 어려운 실정이다. 따라서, 타 공여기관과의 파트너십 강화 노력의 일환으로 $\mathrm{KOICA}$ 해외사무소 실무인력 증대가 시급하다. 그리고 2015년까지 두 배로 확대될 ODA의 효율적 관 리, 현장중심의 개발협력 강화, $\mathrm{CPS}$ 의 효과적 관리를 위해서도 해외사무소의 실무인력 증대는 $\mathrm{KOICA}$ 의 부산이후 체제이행에 있어서 필수요건이라 할 수 있겠다.

또한 증가하는 인력의 지속적인 교육과 이해 및 정보의 원활한 교류를 위한 기관 내 커뮤니케이션 개선이 이루어져야 할 것이다. 이미 영국의 DFID와 스웨덴의 Sida는 원조효과성 강화와 파리선언의 효과적인 이행을 위하여 원조기관 내 커뮤니케이션을 위한 개혁을 시도하였고, 상당히 긍정적인 결 과를 가져왔다. 17 ) 이러한 경험을 바탕으로 KOICA 본부와 각 해외사무소 간의 커뮤니케이션 강화를 위한 개선방안도 고려되어야 할 것이다.

\section{IV. 결어}

금번 부산에서 열린 세계개발원조총회는 국제사회의 한국 개발경험에 대한 관심을 증대시키는 효 과와 함께, 한국의 국제 개발협력을 위한 적극적 활동을 이끄는 계기가 되었다. 부산총회에서 공약한 내용을 일관성있게 추진하며 한국은 원조 선진화를 위해 더욱 박차를 가해야 할 것이다. 이를 위해 부산총회를 중심으로 본 연구가 제안한 수원국 주인의식 강화를 위한 CPS 활용, 결과중심을 위한 성 과평가틀 통합관리 및 개발사업 프로그램화, 포괄적 개발 파트너십 강화를 위한 삼각협력 지원 강화, 투명성 및 상호책임성 강화를 위한 정보공개 심화, 최빈국 및 취약국에 대한 체계적 지원 고려, 새로 운 글로벌 파트너십을 위한 타 공여기관과의 협력 강화, 해외사무소 실무인력 증대 및 본부와 해외사 무소간 커뮤니케이션 개선의 일곱가지 방안을 바탕으로, 한국정부 및 KOICA는 보다 구체적인 부산 이후 이행체제를 위한 행동계획을 마련하여 개발협력의 역량 강화 및 개발효과성과 세계 빈곤퇴치에 기여할 수 있어야 할 것이다. 마지막으로, 부산 공약 이행을 위한 정책수립에 있어서 KOICA의 원조 경험과 실제를 반영한 현실적 정책입안 방안이 마련되어야 할 것이다.

15) http://www.tzdpg.or.tz

16) 그 외 3 명의 탄자니아 해외사무소 인력은 봉사단 관리를 담당하고 있다.

17) DFID, 2006; Sida, 2006 


\section{참고문헌}

\section{1. 국내문헌}

권혁주, 이환성, 배재현 (2011). 한국 ODA의 분쟁 및 취약국 지원 방안. 한국국제협력단. 박명지 (2011). 한국 무상 ODA의 파트너십 제고 방안 연구 - 정부·공공기관의 협력 체계 구축을 중심으로. 한국국제협력단.

이현주 (2009). KOICA 사업의 삼각협력 추진방안. 한국국제협력단.

(2010a). 수원국 공공 재정관리 및 조달시스템 활용방안. 한국국제협력단.

(2010b). 한국 ODA의 프로그램형 접근법(PBA) 도입방안. 한국국제협력단.

임소진 (2011). 부산 세계개발원조총회의 성과와 한국 ODA의 과제. 개발협력 정책과 이슈

3호 (2011.12월). 한국국제협력단.

정우진, 정유아 (2011). 현장중심의 개발협력 방안 - KOICA 무상협력 사업을 중심으로. 한국국제협력단.

한국국제협력단 (2011). KOICA 선진화를 위한 2011년 KOICA-CPS 추진계획(안) - 내부 정책문서.

\section{2. 국외문헌}

Abdel-Malek, T. and B. Koenders (2011). Progress towards More Effective Aid: What Does the Evidence Show?

Birdsall, N. and H. Kharas (2010). Quality of Official Development Assistance Assessment. Center for Global Development, Washington, DC.

(2011). Measuring the Quality of Aid: QuODA Second Edition. Center for Global Development, Washington, DC.

DFID (2006). DFID's Medium Term Action Plan on Aid Effectiveness: Our Response to the Paris Declaration. Donor Policy and Partnerships Team, Policy Division.

Lim, S. (2011). Western Inspired Paris Declaration: What Works and What Doesn't.

Working Paper No. 4. Manchester: Centre for Organisations in Development. 
OECD (2005). Paris Declaration on Aid Effectiveness.

(2008a). Accra Agenda for Action.

(2008b). Compendium of Donor Reports on Implementing the Paris Declaration - Vol.1: Summary of Emerging Trends.

(2008c). Compendium of Dおnor Reports on Implementing the Paris Declaration - Vol.2: Donor Self-Assessments.

(2008d). Development Cooperation of the Republic of Korea: DAC Special Review. Paris, OECD.

(2011a). Aid Effectiveness 2005-10: Progress in Implementing the Paris Declaration.

(2011b). Busan Partnership for Effective Development Cooperation.

(2011c). Meeting of the Group of HLF4 Outcome Document Sherpas Draft

Summary Record of the First Meeting. OECD-DCD/DAC/EFF/M(2011)4/PROV.

Publish What You Fund (2011). Pilot Aid Transparency Index 2011.

Roodman, D. (2011). The Commitment to Development Index: 2011 Edition. Center for Global Development, Washington, DC.

Sida (2006). Sida Action Plan 2006-2008 for Increased Aid Effectiveness.

Wood, B., D. Kabell, F. Sagasti and N. Muwanga (2008). Synthesis Report on the First Phase of the Evaluation of th Implementation of the Paris Declaration. Copenhagen, Ministry of Foreign Affairs of Denmark.

Wood, B., J. Betts, F. Etta, J. Gayfer, D. Kabell, N. Ngwira, F. Sagasti and M. Samaranayake (2011). The Evaluation of the Paris Declaration, Final Report. Copenhagen, Danish Institute for International Studies. 